\title{
National Marine Fisheries Service Habitat Conservation Efforts in the Southeastern United States for 1988
}

\author{
ANDREAS MAGER, Jr.
}

Introduction

Since 1970, the National Marine Fisheries Service(NMFS) Southeast Region has been heavily involved in the review of development activities in wetland habitats that support marine, estuarine, and anadromous fishery resources. NMFS mandates to provide analyses and recommendations on activities that affect its trust resources are provided mainly under authority of the Fish and Wildlife Coordination Act. This Act requires that fish and wildlife interests be given equal consideration with other factors in Federal decisions on coastal development projects. These responsibilities, as they relate to living marine resources, are shared with the U.S. Fish and Wildlife Service (FWS) under Reorganization Plan Number 4 that placed the Interior Department's Bureau of Commercial Fisheries

Andreas Mager, Jr., is with the Habitat Conservation Division, National Marine Fisheries Service, NOAA, 9450 Koger Boulevard, St. Petersburg, FL 33702 .

ABSTRACT-Dataquantifying the area of habitat affected by Federal programs that regulate development in coastal zones of the southeastern United States are provided for 1988. The National Marine Fisheries Service (NMFS) made recommendations on 3,935 proposals requiring Federal permits or licenses to alter wetlands. A survey of 977 of these activities revealed that 359,876 acres of wetlands that support fishery resources under NMFS purview were proposed for some type of alteration or manipulation. Almost 95 percent of this acreage was for impounding and/ or manipulation of water levels in Louisiana marshes. The NMFS did not object to alteration of 173,284 acres and recommended the conservation of 186,592 acres. To offset habitat losses, 1,827acres of mitigation were under the Department of Commerce's National Oceanic and Atmospheric Administration as the NMFS. Furthermore, the U.S. Court of Appeals ruled that the U.S. Army Corps of Engineers (COE) could deny a dredge and fill permit required by Section 10 of the River and Harbor Act of 1899 based on adverse effects to fish and wildlife and not just navigation alone (USCA, 1970). The Clean Water Act extended protection to wetlands above the mean high tide line.

The NMFS habitat conservation program in the southeast is largely geared toward involvement with proposals to alter coastal wetlands (fishery habitat). This process is described in detail by Lindall and Thayer (1982) and Mager and Thayer (1986). Simply put, fishery habitats are wetlands and other coastal habitats that provide food, cover, and other functions such as nursery or feeding grounds, and which are vital for the continued production of fishery resources (Smith et al., 1966; Douglas and Stroud, 1971; Turner, 1977; Peters et al., 1979;

recommended by the NMFS or proposed by applicants and/or the Corps of Engineers (COE). From 1981 to 1988 the NMFShasprovided indepth analyses on 8,385 projectsproposing the alteration of at least 656,377 acres of wetlands.

Afollow-up survey on the disposition of 339 permits handled by the COE during 1988 revealed that the COE accepted NMFS recommendations on 68 percent. On a permit-bypermit basis, 13 percent of NMFS recommendations were partially accepted, 17 percent were completely rejected, and 2 percent were withdrawn. The permit requests tracked by the NMFS proposed the alteration of 2,674 acres of wetlands. The COE issued permits to alter 847 acres or 32 percent of the amount proposed.
Thayer and Ustach, 1981). Wetlands also provide many other benefits such as erosion protection, a buffer against storms, production of wildlife other than fish, water quality maintenance, aesthetics, and recreation.

Each year the COE receives thousands of requests for permits to alter wetlands. In addition, many projects are proposed by the COE under their own civil works program. Alterations range from construction of docks or other minor structures to massive dredge, fill, and impoundment projects. These activities can result in considerable destruction of fishery habitat if implemented. However, under the legislation discussed earlier, the $\mathrm{COE}$ is required to consult with the fish and wildlife agencies and provide detailed plans and specification for their review and comment. The comments of the fish and wildlife agencies are considered in the COE's determination on whether a project should be authorized, modified, or denied; but the final decision rests with the $\mathrm{COE}$.

Although NMFS recommendations to the COE are designed to minimize adverse project impacts on fishery resources, in the 1970's, these recommendations generally had a minimal effect on wetlands conservation. The COE granted most of the permits to alter wetlands without including in them the recommendations of the NMFS. The importance of coastal wetlands to fishery production was not well understood or documented and the "opinions" of the NMFS were not able to compete well with reported benefits of the projects (mostly economics) in the COE's public interest review. Moreover, habitat losses involved in the various regulatory programs were often considered insignificant, even though the 
amount (i.e., cumulative effect), type, and geographical distribution of the altered habitat was generally unknown.

To improve the acceptance of its recommendations, the NMFS began to compile information showing the quantity of alterations involved and the significance of the Federal regulatory and construction programs. Another important purpose of the program was to determine the effectiveness of NMFS recommendations. This information helps to determine the cumulative amount of habitat alterations regulated by the $\mathrm{COE}$ and others so that more convincing arguments can be made to prevent avoidable damage to wetlands and fisheries production. It alsoallows the effectiveness of the habitat conservation program to be monitored so necessary modifications can be made. The NMFS Southeast Fisheries Center also has conducted much research which better explains and documents the importance of wetlands to fishery production. More recent research also is addressing mitigation options such as creation and/or enhancement of wetlands.

This paper presents the results of the NMFS' 1988 habitat conservation efforts related mostly to COE permit and civil works programs. The information we provide covers mainly the coastal wetlands in the NMFS Southeast Region (North Carolina to Florida to Texas plus Puerto Rico and the U.S. Virgin Islands). These data build on the detailed habitat information on 7,408 of the approximate 32,000 projects reviewed by the NMFS Habitat Conservation Division in the southeastern United States between 1981 and 1987. During this period, more than 300,000 acres of wetlands were proposed for alteration (Mager and Ruebsamen, 1988). This is alarming in view of the coastal wetland loss rate in the United States estimated by Alexander et al. (1986) at 20,000 acres per year for the last 25 years. This amount does not include losses of submerged aquatic plants about which there is little information. The rate of marshland loss in the southeast, for example in Louisiana, is likely even greater.

\section{Materials and Methods}

For each proposed habitat alteration under Federal purview, information was recorded to allow NMFS retrieval by project identification number; location by state, county, and proximity to major and secondary waterbodies; and dates such as public notice date and when responded. Data also include the kind of activity involved (e.g., permit application, Federal project, etc.); the type of project being reviewed (e.g., bulkhead, dock, maintenance dredging, navigation channel, marsh management, power plant, housing development, etc.); and whether the NMFS objected to, recommended modifications of, or approved the activity. The procedure is detailed in Lindall and Thayer (1982), Mager and Thayer (1986), and Mager and Keppner (1987).

The NMFS also tracked the impact in acres of wetlands potentially affected by a given proposed activity. The acreage values presented for projects surveyed during 1988 were obtained from onsite reviews by NMFS contractors or NMFS biologists, from public notices, and from project plans that were adequate to determine the acreage and habitat types proposed for alteration. The NMFS tracked individual actions by the amount of potential impact (i.e., dredge, fill, drain, impound); the amount of habitat modification the NMFS accepts or does not object to; and the amount of habitat potentially conserved.

The NMFS also surveyed project permits approving construction in wetlands that were issued by the COE. Those projects on which we 1) were notified by the COE that a permit has been issued, 2) had accurate information on the area and kind of wetlands requested for alteration, and 3 ) could determine the area of alteration that the COE actually permitted, were logged on a computer. The NMFS also recorded COE acceptance, partial acceptance, or rejection of its recommendations.

\section{Results}

The NMFS evaluated and responded to 3,935 proposals for construction in wetlands in the southeastern coastal states during 1988. Most of the actions $(3,417)$ involved evaluation of projects advertised by the COE pursuant to the River and Harbor Act and/or the Clean Water Act. The NMFS also reviewed 46 pro- posed Federal civil works projects such as major navigation and maintenance dredging (under authority of the Fish and Wildlife Coordination Act), 42 proposals to construct bridges and/or causeways under the jurisdiction of the U.S. Coast Guard, and 430 projects that illegally altered wetlands. For the projects reviewed, 2,604 (66 percent) received a "no objection"' response because impacts on fishery habitat were minimal, impacts were offset by appropriate mitigation, or the projects were inland and were not used by fishery resources under NMFS purview. In-depth review was given to 714 (18 percent) of the projects because of probable direct or cumulative adverse effects to fishery resources. For 616 projects (16 percent) we coordinated with other agencies such as the FWS and the Environmental Protection Agency (EPA) because their resources and interests were affected to an equal or greater extent than ours or because of limited manpower. Only one project was not evaluated because it was offshore where the COE does not accept recommendations other than those pertaining to navigation or national defense.

NMFS habitat conservation efforts relating to a sample of the projects reviewed during 1988 are discussed below by state, the type of proposed alteration (i.e., dredge, fill, other), the area of alteration proposed by applicants and accepted and potentially conserved by the NMFS, the types and amounts of wetlands involved, the types of projects encountered (marinas, impoundments, etc.), the Federal programs that regulate wetland alterations (e.g., Section 10,404, etc.), cumulative totals, and how NMFS comments and recommendations were treated.

\section{Dredging}

Approximately 4,011 acres of wetlands were proposed for dredging by the 977 projects surveyed (Table 1, column 2). Most of the dredging was proposed in North Carolina and Texas (30 percent each), Louisiana (18 percent), Georgia (8 percent), Florida (6 percent), and South Carolina (4 percent). The remaining 2 percent was proposed in Alabama, Mississippi, Puerto Rico, and the U.S. Virgin Islands. More than 75 percent of the pro- 
posed dredging was to maintain existing channels and boat basins. The NMFS opposed the dredging of 1,684 acres because habitats important to fisheries resources would be altered (Table 1, column 8), but accepted the dredging of 2,327 acres because effects on fishery resources were determined to be minimal and only short-term (Table 1, column 5).

Most of the area potentially conserved involved mainly one project in Galveston Bay, Tex., where a wider and deeper channel from the mouth of the Bay to Houston (Houston Ship Channel) is proposed by the COE. There is extensive opposition to the proposed work, but the COE has not yet advised the NMFS whether or not they still will seek authorization for construction. Of the remaining area potentially conserved, 13 percent was in Louisiana, 9 percent in Georgia, and 6 percent in Florida. About 11 percent was scattered in the remaining states.

\section{Filling}

About 14,632 acres of wetlands were proposed for filling (Table 1, column 3). More than 78 percent was in Texas, followed by Louisiana (11 percent), Florida (6 percent), and North Carolina (4 percent). The NMFS did not oppose the filling of 2,092 acres (Table 1, column 6). Most of this latter amount was in Louisiana (59 percent), North Carolina (21 percent), Florida (11 percent), and Georgia (6 percent). Potential acreage conserved was 12,540 acres (Table 1, column 9), but more than 11,000 acres of this amount involves filling associated with the Houston Ship Channel project. Such projects may have a large impact on our habitat conservation program in any given year because of their size, complexity, and the length of time required for resolution.

\section{Other Impacts}

This category is used as a catch-all, but most activities recorded here involve impounding and draining of wetlands. Approximately 341,233 acres were proposed to be altered (Table 1, column 4). Most of this acreage was in Louisiana and involved four separate applications by a major corporate landowner. These applications proposed the maintenance of 214 earthen plugs, 373 fixed crest weirs, and three gated water control structures for water level and marsh management purposes. After extensive review of research information and 1985 color infrared aerial photographs, NMFS biologists concluded that maintenance of about 10 percent of the plugs and 30 percent of the weirs, would potentially unacceptably impact migrations of fish and invertebrates and habitat quality in about 155,000 acres of wetlands. This conclusion was formed because the wetlands at the sites had continued to deteriorate despite management.

The NMFS also did not find any evidence of plugs or structures that required maintenance. It further appeared that existing structures were causing marsh loss through impoundment, fishery migratory patterns were being disrupted, and that, in the case of the gated structures, no management plan was proposed. The NMFS recommended these individual sites not be authorized, but rather that they be assessed separately at the time maintenance on each is proposed toallow a more detailed evaluation.

Many of the remaining plugs and structures affecting an estimated 168,300 acres of coastal wetlands had been maintained since the 1950's. The NMFS did not object to the continued maintenance of these structures because they were located in areas of low value to living marine resources, the marsh habitats influenced by the structures did not appear adversely impacted, and structures and plugs were well maintained and functional. Removal of the existing functional plugs and weirs also could have resulted in greater ecological damage. Access by fish and shellfish was being maintained to some extent, but removal of structures could have increased marsh loss by erosion and through altered hydrology and changes in salinity patterns.

\section{Mitigation}

The NMFS recommended 1,827 acres of mitigation (Table 1, column 11). Most mitigation acreage was in Louisiana (76 percent), followed by Georgia and North Carolina (6 percent each), Florida (5 per-

Table 1.-NMFS southeastern United States 1988 habitat conservation efforts by state.

\begin{tabular}{|c|c|c|c|c|c|c|c|c|c|c|c|}
\hline \multirow[b]{2}{*}{ State } & \multirow[b]{2}{*}{$\begin{array}{l}N^{1} \\
(1)^{3}\end{array}$} & \multicolumn{3}{|c|}{$\begin{array}{l}\text { Acreage proposed } \\
\text { for alteration }\end{array}$} & \multicolumn{3}{|c|}{$\begin{array}{c}\text { Acreage accepted } \\
\text { by NMFS }\end{array}$} & \multicolumn{3}{|c|}{$\begin{array}{l}\text { Potential acreage } \\
\text { conserved }\end{array}$} & \multirow{2}{*}{ 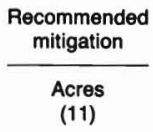 } \\
\hline & & $\begin{array}{l}\text { Dredge } \\
\text { (2) }\end{array}$ & $\begin{array}{l}\text { Fill } \\
\text { (3) }\end{array}$ & $\begin{array}{l}\text { Other } \\
\text { (4) }\end{array}$ & $\begin{array}{l}\text { Dredge } \\
\text { (5) }\end{array}$ & $\begin{array}{l}\text { Fill } \\
(6)\end{array}$ & $\begin{array}{l}\text { Other } \\
(7)\end{array}$ & $\begin{array}{l}\text { Dredge } \\
(8)\end{array}$ & $\begin{array}{l}\text { Fill } \\
\text { (9) }\end{array}$ & $\begin{array}{l}\text { Other } \\
(10)\end{array}$ & \\
\hline Alabama & 20 & 52.5 & 9.5 & 0.0 & 5.3 & 2.9 & 0.0 & 47.2 & 6.6 & 0.0 & 2.6 \\
\hline Florida & 306 & 225.4 & 845.1 & 12.0 & 122.7 & 225.7 & 1.3 & 102.7 & 619.4 & 10.7 & 94.2 \\
\hline Georgia & 63 & 342.8 & 179.4 & 0.0 & 186.9 & 117.7 & 0.0 & 155.9 & 61.7 & 0.0 & 112.1 \\
\hline Louisiana & 93 & 737.0 & $1,548.8$ & $340,305.1$ & 512.6 & $1,239.0$ & $168,800.0$ & 224.4 & 309.8 & $171,505.1$ & 1,393.1 \\
\hline Mississippi & 8 & 27.5 & 6.5 & 0.0 & 2.1 & 0.1 & 0.0 & 25.4 & 6.4 & 0.0 & 18.0 \\
\hline N. Carolina & 281 & $1,220.8$ & 508.5 & 666.8 & $1,183.5$ & 437.7 & 50.9 & 37.3 & 70.8 & 615.9 & 105.8 \\
\hline Puerto Rico & 3 & 11.8 & 1.5 & 0.0 & 0.0 & 0.0 & 0.0 & 11.8 & 1.5 & 0.0 & 0.0 \\
\hline S. Carolina & 126 & 174.3 & 103.7 & 161.5 & 109.0 & 46.5 & 0.2 & 65.3 & 57.2 & 161.3 & 29.9 \\
\hline Texas & 75 & $1,217.8$ & $11,425.6$ & 87.2 & 204.7 & 22.1 & 13.0 & $1,013.1$ & $11,403.5$ & 74.1 & 71.4 \\
\hline Virgin Islands & 2 & 1.4 & 3.2 & 0.0 & 0.0 & 0.1 & 0.0 & 1.3 & 3.2 & 0.0 & 0.0 \\
\hline Total & 997 & $4,011.3$ & $14,631.8$ & $341,232.6$ & $2,326.8$ & $2,091.8$ & $168,865.4$ & $1,684.4$ & $12,540.1$ & $172,367.2$ & $1,827.1$ \\
\hline
\end{tabular}

${ }^{1} \mathrm{~N}$ refers to the number of projects for which acreage data could be obtained.

${ }^{2}$ This impact category is a catchall, but the acreage presented includes mainly marsh management projects, impoundments, and wetland drainage works.

${ }^{3}$ Numbers in parentheses refer to columns discussed in the text. 
Table 2.-Acres of habitat proposed for alteration by ecological system ${ }^{1}$.

\begin{tabular}{|c|c|c|}
\hline \multirow[t]{3}{*}{ Habitat type } & \multicolumn{2}{|c|}{ Ecological system } \\
\hline & \multicolumn{2}{|c|}{ Estuarine } \\
\hline & Subtital & Intertidal \\
\hline Aquatic bed & 129.7 & 0.3 \\
\hline Flat & 47.4 & 118.2 \\
\hline Reef & 0.0 & 0.9 \\
\hline Unc. bottom ${ }^{2}$ & $181,165.3$ & 2.5 \\
\hline Beach/bar & 0.0 & 1.2 \\
\hline Emergent & 0.0 & $173,738.2$ \\
\hline Forested & 0.0 & 118.3 \\
\hline Streambed & 0.0 & 3.0 \\
\hline Scrub/shrub & 0.0 & 6.5 \\
\hline \multirow[t]{3}{*}{ Total } & $181,342.4$ & $173,989.1$ \\
\hline & \multicolumn{2}{|c|}{ Marine } \\
\hline & Subtidal & Intertidal \\
\hline Aquatic bed & 4.1 & 0.0 \\
\hline Unc. bottom & 152.4 & 0.0 \\
\hline Beach/bar & 0.0 & 2.5 \\
\hline Flat & 0.0 & 1.1 \\
\hline \multirow[t]{2}{*}{ Total } & 156.5 & 3.6 \\
\hline & Palustrine & \\
\hline Emergent & $2,168.0$ & \\
\hline Forested & $1,662.0$ & \\
\hline Scrub/shrub & 105.6 & \\
\hline Total & $3,935.6$ & \\
\hline
\end{tabular}

\begin{tabular}{lcc} 
& \multicolumn{2}{c}{ Lacustrine } \\
\cline { 2 - 3 } & Limnetic & Littoral \\
Open water & 0.8 & 22.0 \\
Emergent & 0.0 & \\
Unc. bottom & 0.0 & \\
Total & 0.8 & \\
& & 25.6
\end{tabular}

\begin{tabular}{|c|c|c|c|c|}
\hline & \multicolumn{4}{|c|}{ Riverine } \\
\hline & Tidal & $\begin{array}{l}\text { Lower } \\
\text { perennial }\end{array}$ & $\begin{array}{l}\text { Upper } \\
\text { perennial }\end{array}$ & $\begin{array}{l}\text { Inter- } \\
\text { mittent }\end{array}$ \\
\hline Emergent & 45.7 & 0.0 & 0.0 & 0.2 \\
\hline Unc. bottom & 306.5 & 66.2 & 2.3 & 0.0 \\
\hline Streambed & 0.0 & 0.0 & 0.0 & 1.2 \\
\hline Total & 352.2 & 66.2 & 2.3 & 1.4 \\
\hline
\end{tabular}

'Follows the Cowardin et al. (1979) wetlands classification system.

2Unconsolidated bottom

cent), and Texas ( 4 percent). Less than 3 percent occurred in the remaining states. The mitigation area is less than in previous years reflecting the agency's concerns that many mitigation projects proposed in the past have not been successful (Race, 1982, 1985) or require a long time to replace the function of the wetland that was altered (Craftet al., 1988). Accord-

Table 3.-Acres ${ }^{1}$ of habltat alterations proposed during 1988 by vegetation or substrate type.

\begin{tabular}{|c|c|c|c|c|}
\hline $\begin{array}{c}\text { Dominant } \\
\text { habitat }\end{array}$ & $\begin{array}{l}\text { Acres proposed } \\
\text { for alteration }\end{array}$ & $\begin{array}{l}\text { Acres accepted } \\
\text { by NMFS }\end{array}$ & $\begin{array}{l}\text { Acres potentially } \\
\text { conserved }\end{array}$ & $\begin{array}{l}\text { Acres recommended } \\
\text { for mitigation }\end{array}$ \\
\hline Algae & 1.1 & 0.4 & 0.7 & 0.1 \\
\hline Black mangrove & 38.4 & 6.8 & 31.6 & 0.5 \\
\hline Black nөedlerush & 153.8 & 18.1 & 135.7 & 4.0 \\
\hline Eelgrass & 1.3 & 0.0 & 1.3 & 0.0 \\
\hline Freshwater marsh & $2,301.0$ & 121.7 & $2,179.3$ & 38.5 \\
\hline \multicolumn{5}{|l|}{ Freshwater submerged } \\
\hline aquatic vegetation & 4.5 & 1.4 & 3.1 & 0.0 \\
\hline Hardwood swamp & $1,767.1$ & 519.4 & $1,247.7$ & 191.6 \\
\hline Manatee grass & 0.2 & 0.0 & 0.2 & 0.0 \\
\hline Miscellaneous & 1.8 & 1.8 & 0.0 & 1.7 \\
\hline Mud & $179,832.2$ & $86,496.4$ & $93,335.8$ & 59.3 \\
\hline Other marsh & $159,240.7$ & $84,101.2$ & $75,139.5$ & 62.9 \\
\hline Oyster reef & 0.9 & 0.0 & 0.9 & 0.0 \\
\hline Red mangrove & 44.9 & 0.6 & 44.3 & 0.7 \\
\hline Saltgrass & $1,744.3$ & 10.8 & $1,733.5$ & 2.6 \\
\hline Saltmeadow cordgrass & $12,238.3$ & 47.8 & $12,190.5$ & $1,240.4$ \\
\hline Sand & $1,728.6$ & $1,591.5$ & 137.1 & 3.2 \\
\hline Shoalgrass & 30.4 & 17.2 & 13.2 & 51.0 \\
\hline Shell & 0.0 & 0.0 & 0.0 & 0.3 \\
\hline Silt & 305.8 & 272.0 & 33.8 & 0.0 \\
\hline Smooth cordgrass & 299.8 & 55.0 & 244.8 & 150.2 \\
\hline Threecorner grass & 5.7 & 4.5 & 1.2 & 0.0 \\
\hline Turtlegrass & 1.7 & 0.1 & 1.6 & 2.8 \\
\hline White mangrove & 39.1 & 5.8 & 33.3 & 10.8 \\
\hline Wigeon grass & 94.1 & 11.5 & 82.6 & 6.5 \\
\hline Total & $359,875.7$ & $173,284.0$ & $186,591.7$ & $1,827.1$ \\
\hline
\end{tabular}

${ }^{1}$ Acreages are based on a sample of 977 projects.

ingly, the main goal of the NMFS is to ensure that a net loss of fishery habitat does not occur. Thus, alternatives are first sought that avoid or minimize damage. For nonwater-dependent projects, wetland alterations are usually opposed since the projects' purpose does not require location in wetlands.

Where a project is water-dependent and where losses of habitat are clearly unavoidable, the NMFS may recommend that such losses be mitigated to the maximum extent practicable (Lindall et al., 1979). The acceptability of a mitigation proposal relates to its potential to restore the functional values of the wetlands to be altered. Accordingly, the NMFS is very conservative in its acceptance of mitigation proposals unless all measures to avoid adverse impacts have been implemented and it is likely that wetland compensation efforts would replace fishery production.

\section{Types of Habitat Proposed for Alteration}

More than 98 percent of all alterations $(355,332$ acres) were proposed in estuarine systems (Table 2). Estuarine subtidal habitats, mostly unconsolidated bottoms, comprised 51 percent of the total. Estuarine intertidal habitat comprised 49 percent of the total; almost all of this was emergent wetlands. Smaller amounts of wetland alterations also were proposed in marine (160 acres), palustrine $(3,936$ acres), lacustrine (26 acres), and riverine (422 acres) ecological systems. For the five ecological systems, unconsolidated bottoms and emergent wetlands comprised 50 percent and 48 percent, respectively, of all the wetlands proposed for alteration.

Most of the unconsolidated bottoms (179,832 acres) were composed of mud, while most of the emergent marsh $(159,241$ acres under "other marsh" in Table 3) could not be separated into dominant vegetation types. Considerable amounts of saltmeadow cordgrass, Spartina patens, (12,238 acres); freshwater marsh $(2,301$ acres); hardwood swamps (1,767 acres); and saltgrass, Distichlis spicata,$(1,744$ acres) were proposed for alteration (Table 3).

\section{Area Regulated by Federal Programs}

Almost all of the proposed fishery habitat alterations reviewed by the NMFS in 
the southeast were under the direct control of the COE. From a sample of 977 projects reviewed by NMFS, about 359,876 acres, or 95 percent of the total area of habitat alterations, were involved in the COE's regulatory program and about 4 percent $(14,929$ acres) were involved in their civil works program (Table 4). The remaining alterations tracked resulted from U.S. Coast Guard bridge permit requests and unauthorized wetland alteration projects.

\section{Area Potentially Impacted by Type of Project}

The projects reviewed included 803 proposals for docks and other minor structures; 646 shoreline altering works such as bulkheads, small fills, groins, and/or ramps; 544 residential housing developments; 391 maintenance dredging projects; 244 oil and gas exploration activities; 241 navigation channels and marinas; 232 bridges and causeways; 192 industrial and commercial developments; 162 miscellaneous activities; 154 water, gas, and/or chemical pipelines; 153 barriers, dams, and/or impoundments; 70 sand, gravel, and other mining operations; 40 electrical transmission lines; 31 irrigation projects; 18 marsh management activities; and 14 beach nourishment projects.

About 95 percent $(340,315$ acres $)$ of the proposed habitat alterations, 97 percent $(168,905$ acres $)$ of the alterations accepted by the NMFS, and 92 percent $(171,411$ acres) of the wetlands area potentially conserved resulted from requests to manage marshes (Table 5). This activity and its significance were detailed above. Almost 13,000 acres of navigation works were proposed, but more than 98 percent of the impacted area was associated with open water disposal of dredged material from proposed new COE Federal navigation channels and deepening and widening of existing channels. Maintenance dredging accounted for 3,208 acres of the alterations reported. Since we believed this would have produced only minor disturbance of fishery habitat, the NMFS accepted most of the acreage proposed (3,010 acres). Material disposal from maintenance dredging was proposed for 1,393 acres of bay bottom, but 1,009
Table 4.-Acres of habitat proposed by applicants and reviewed by NMFS under the various Federal regulatory programs.

\begin{tabular}{|c|c|c|c|c|c|}
\hline $\begin{array}{r}\text { Project } \\
\text { kind }^{\prime}\end{array}$ & $\mathrm{N}^{2}$ & $\begin{array}{c}\text { Acres } \\
\text { proposed } \\
\text { by } \\
\text { applicants }\end{array}$ & $\begin{array}{c}\text { Acres } \\
\text { accepted } \\
\text { by } \\
\text { NMFS }\end{array}$ & $\begin{array}{l}\text { Potential } \\
\text { acres } \\
\text { conserved }\end{array}$ & $\begin{array}{l}\text { Miti- } \\
\text { gation } \\
\text { recom- } \\
\text { mended }\end{array}$ \\
\hline 10 & 141 & 621.5 & 547.1 & 74.4 & \\
\hline $10 / 404$ & 519 & $342,356.1$ & $169,682.0$ & $172,674.1$ & 35.5 \\
\hline 404 & 178 & & 370 & & \\
\hline CFP & 23 & $14,928.8$ & $2,635.1$ & $12,293.7$ & 983. \\
\hline CG & 8 & 18.2 & 17.1 & 1.1 & 21.0 \\
\hline 110 & 11 & 4.8 & 2.2 & 2.6 & 0.3 \\
\hline |10/104 & 40 & & 22.8 & & \\
\hline 1404 & 57 & 162.6 & 6.8 & 155.8 & 43.2 \\
\hline otal & & & & 91.7 & \\
\hline
\end{tabular}

$10=$ projects requested pursuant to Section 10 of the River and Harbor Act; $\mathbf{4 0 4}=$ projects requested pursuant to the Clean Water Act: $10 / 404=$ projects advertised under Section 10 and 404 authorities: CFP = Corps Federal Project: $C G=$ U.S. Coast Guard bridge/causeway permit application; 110 1404 , and $110 / 404$ = unauthorized projects.

1404 , and $110 / 404=$ unauthorized projects.
${ }^{2} \mathrm{~N}$ represents the number of projects of each type sampled

acres were included in wetland mitigation efforts.

\section{Cumulative Totals}

Overall, nearly 359,876 acres of wetlands were proposed for alteration during 1988. The NMFS did not object to the alteration of 173,284 acres and 186,592 acres could be conserved if NMFS recommendations are accepted by the regulatory agencies. The NMFS also recommended restoration, generation, and enhancement of at least 1,827 acres to mitigate for adverse project impacts.

The NMFS did not oppose the alteration of 168,900 acres of wetlands proposed for continued hydrologic management in Louisiana; 3,028 acres of maintenance dredging and dredged material disposal in silt, mud, and sand substrate; and about 643 acres of freshwater wetlands where NMFS trust resources were not affected. Of the 173,284 acres of wetland alterations the NMFS did not oppose, an estimated 171,970 acres of alterations would have minimally impacted marine, estuarine, or anadromous fishery resources. The remaining 1,314 acres of alterations were offset by 1,827 acres of mitigation (a ratio of 1.4:1). Specifically, 1,763 acres of the mitigation requested was for vegetated wetlands, including more than 60 acres of submerged aquatic vegetation.

Between 1981 and 1987 more than
Table 5.- Acres of habltat alterations requested by applicants and reviewed by NMFS for various types of projects revlewed during 1988.

\begin{tabular}{|c|c|c|c|c|c|}
\hline $\begin{array}{l}\text { Project } \\
\text { type }\end{array}$ & $N^{2}$ & $\begin{array}{c}\text { Acres } \\
\text { proposed } \\
\text { by } \\
\text { applicants }\end{array}$ & $\begin{array}{c}\text { Acres } \\
\text { accepted } \\
\text { by } \\
\text { NMFS }\end{array}$ & $\begin{array}{l}\text { Potential } \\
\text { acreage } \\
\text { conserved }\end{array}$ & $\begin{array}{l}\text { Miti- } \\
\text { gation } \\
\text { recom- } \\
\text { mended }\end{array}$ \\
\hline BA & 37 & $1,066.7$ & 67.7 & 999.0 & 43.4 \\
\hline $\mathrm{BE}$ & 4 & 50.0 & 50.0 & 0.0 & 0.0 \\
\hline BR & 94 & 234.6 & 167.3 & 67.3 & 141.1 \\
\hline DO & 13 & 1.5 & 0.2 & 1.3 & 0.0 \\
\hline $\mathrm{HO}$ & 203 & 725.5 & 119.4 & 606.1 & 33.9 \\
\hline IN & 71 & 378.6 & 94.7 & 283.9 & 57.0 \\
\hline IR & 10 & 107.9 & 34.5 & 73.4 & 80.0 \\
\hline MD & 101 & $3,028.1$ & $3,010.1$ & 18.0 & $1,009.3$ \\
\hline MI & 4 & 110.2 & 79.2 & 31.0 & 1.1 \\
\hline MM & 12 & $340,315.4$ & $168,904.6$ & $171,410.8$ & 100.0 \\
\hline NA & 110 & $12,876.1$ & 311.1 & $12,565.0$ & 70.7 \\
\hline OI & 37 & 521.1 & 277.9 & 243.2 & 143.6 \\
\hline OT & 26 & 81.8 & 32.5 & 49.3 & 54.3 \\
\hline $\mathrm{PI}$ & 25 & 76.0 & 72.6 & 3.4 & 69.8 \\
\hline $\mathrm{SH}$ & 226 & 301.5 & 61.5 & 240.0 & 22.3 \\
\hline TR & 4 & 0.7 & 0.7 & 0.0 & 0.6 \\
\hline Total & 977 & $359,875.7$ & $173,284.0$ & $186,591.7$ & $1,827.1$ \\
\hline
\end{tabular}

'(BA) barriers and impoundments; (BE) beach nourishmen projects; (BR) bridges, roads, and causeways; (DO) docks and other minor structures; $(\mathrm{HO})$ housing development; (IN) commercial and industrial development, etc. (IR) irrigation and (MD) drainage works; (MD) main) mineral exploration; (MM) marsh management areas; (NA) navigation projects, marinas, etc.; (OI) oil and gas construction; (OT) unclassified; (PI) oil, gas, and chemical pipelines (SH) bulkheads, small fills, groins, etc.; (TR) transmission lines.

${ }^{2} \mathrm{~N}$ refers to the number of projects where data is available on the area of proposed alteration.

Table 6.-NMFS southeastern United States habltat conservation efforts from 1981 to 1988.

\begin{tabular}{|c|c|c|c|c|c|}
\hline Year & $N^{\prime}$ & $\begin{array}{c}\text { Acres } \\
\text { proposed } \\
\text { for } \\
\text { alteration }\end{array}$ & $\begin{array}{c}\text { Acres } \\
\text { accepted } \\
\text { by } \\
\text { NMFS }\end{array}$ & $\begin{array}{c}\text { Acres } \\
\text { poten- } \\
\text { tially } \\
\text { conserved }\end{array}$ & $\begin{array}{c}\text { Acres } \\
\text { gation } \\
\text { miti- } \\
\text { gated }\end{array}$ \\
\hline 1981 & 811 & 7,949 & 2,868 & 5,081 & 2,471 \\
\hline 1982 & 1,059 & 81,184 & 21,831 & 59,353 & 7,910 \\
\hline 1983 & 825 & 20,778 & 8,658 & 12,120 & 26,775 \\
\hline 1984 & 888 & 8,606 & 3,981 & 4,625 & 54,050 \\
\hline 1985 & 1,802 & 65,670 & 11,161 & 54,509 & 19,200 \\
\hline 1986 & 969 & 90,559 & 70,838 & 19,721 & 49,713 \\
\hline 1987 & 1,054 & 21,755 & 8,135 & 13,620 & 7,139 \\
\hline 1988 & 977 & 359,876 & 173,284 & 186,592 & 1,827 \\
\hline tal & 8 & 656,377 & 300,756 & 355,621 & 169,085 \\
\hline
\end{tabular}

${ }^{1} \mathrm{~N}$ refers to the number of projects sampled.

296,501 acres of wetlands were proposed for alteration by 7,408 water development projects (Mager and Ruebsamen, 1988). The addition of 1988 data brings the total area proposed for alterations to 656,377 acres by 8,385 water development projects (Table 6). The amount of wetlands accepted for alteration by the NMFS, the amount potentially conserved, 
and the amount potentially mitigated total $300,756,355,621$, and 169,085 acres, respectively, for the 8 years we have collected data.

\section{Effect of NMFS \\ Recommendations}

NMFS effectiveness was determined from a survey of 339 issued permits for which information had been provided by the COE to allow an assessment on whether or not NMFS comments and recommendations had been accepted (Table 7). The overall acceptance of NMFS recommendations by the $\mathrm{COE}$ was about 68 percent. NMFS recommendations were partially accepted and completely rejected on 13 percent and 17 percent of the reviews, respectively. The district with the highest acceptance of NMFS recommendations was the Wilmington District (96 percent, followed by the Charleston District (76 percent), Galveston District (64 percent), Mobile District ( 58 percent), Savannah District (56 percent), New Orleans District (44 percent), and the Jacksonville District (29 percent). Seven of the permit requests were withdrawn by the applicants.

The amount of habitat permitted for alteration by the COE and accepted by the NMFS was determined by COE district for 332 authorizing documents that were evaluated. Copies of the issued permits detailing what was permitted by the COE and previously obtained NMFS data on the area proposed for alteration allowed this analysis. More than 2,673 acres of wetlands were proposed for alteration by the 332 projects (Table 8 ). The NMFS did not oppose the alteration of 625 acres $(23$ percent of the amount proposed), thereby asking that 2,049 acres be conserved. The COE, however, permitted 32 percent of the area proposed for alteration by applicants (847 acres) or 8 percent more than recommended by NMFS. The COE permitted 79 percent of the 515 acres of mitigation recommended by the NMFS or proposed by applicants.

\section{Discussion}

The area of proposed habitat alterations reported herein are very conservative. Not all alterations were evaluated because of the large number of activities

Table 7.-Treatment of NMFS recommendations on permits issued by Corps of Engineers District (COE).

\begin{tabular}{|c|c|c|c|c|c|c|c|c|c|}
\hline \multicolumn{2}{|l|}{$\begin{array}{l}\mathrm{COE} \\
\text { District }\end{array}$} & \multicolumn{2}{|c|}{$\begin{array}{c}\text { NMFS } \\
\text { recommendations } \\
\text { accepted }\end{array}$} & \multicolumn{2}{|c|}{$\begin{array}{c}\text { NMFS } \\
\text { recommendations } \\
\text { partially } \\
\text { Naccepted }\end{array}$} & \multicolumn{2}{|c|}{$\begin{array}{c}\text { NMFS } \\
\text { recommendations } \\
\text { rejected }\end{array}$} & \multicolumn{2}{|c|}{$\begin{array}{l}\text { Applications } \\
\text { withdrawn }\end{array}$} \\
\hline Charleston & 32 & 25 & $(78.2)^{2}$ & 1 & (3.1) & 5 & (15.6) & 1 & (3.1) \\
\hline Galveston & 38 & 24 & (63.2) & 7 & $(18.4)$ & 4 & (10.5) & 3 & (7.9) \\
\hline Jacksonville & 73 & 21 & (28.8) & 25 & (34.2) & 27 & $(37.0)$ & 0 & $(0.0)$ \\
\hline Mobile & 12 & 7 & $(58.4)$ & 1 & (8.3) & 4 & (33.3) & 0 & $(0.0)$ \\
\hline New Orleans & 34 & 15 & (44.1) & 10 & (29.4) & 8 & (23.5) & 1 & (3.0) \\
\hline Savannah & 12 & 6 & $(50.0)$ & 1 & (8.3) & 3 & $(25.0)$ & 2 & (16.7) \\
\hline Wilmington & 138 & 133 & (96.4) & 0 & $(0.0)$ & 5 & (3.6) & 0 & $(0.0)$ \\
\hline Totals & 339 & 231 & (68.1) & 45 & (13.3) & 56 & (16.5) & 7 & (2.1) \\
\hline
\end{tabular}

${ }^{1} \mathrm{~N}$ refers to number of projects sampled.

${ }^{2}$ Values in parentheses represent percent of $\mathrm{N}$ for each category.

Table 8.-Acres of habitat permitted for alteration over NMFS objections.

\begin{tabular}{|c|c|c|c|c|c|c|c|c|c|}
\hline \multirow{2}{*}{$\begin{array}{l}\mathrm{COE} \\
\quad \text { District } \\
\text { Charleston }\end{array}$} & \multirow{2}{*}{$\frac{N^{1}}{31}$} & \multirow{2}{*}{$\begin{array}{c}\begin{array}{c}\text { Acreage } \\
\text { proposed by } \\
\text { applicants }\end{array} \\
250.5\end{array}$} & \multicolumn{2}{|c|}{$\begin{array}{c}\text { Acreage } \\
\text { NMFS } \\
\text { accepted or did } \\
\text { not object to }\end{array}$} & \multicolumn{2}{|c|}{$\begin{array}{c}\text { Acreage } \\
\mathrm{COE} \\
\text { permitted }\end{array}$} & \multirow{2}{*}{$\begin{array}{c}\begin{array}{c}\text { Percent } \\
\text { differ- }^{2} \\
\text { ence }\end{array} \\
(19.2)\end{array}$} & \multirow{2}{*}{$\begin{array}{c}\begin{array}{c}\text { Acreage } \\
\text { NMFS } \\
\text { recommended } \\
\text { mitigation }\end{array} \\
1.0\end{array}$} & \multirow{2}{*}{$\begin{array}{c}\begin{array}{c}\text { Acreage } \\
\text { COE } \\
\text { permitted } \\
\text { mitigation }\end{array} \\
0.8\end{array}$} \\
\hline & & & 11.1 & $(4.4)^{3}$ & 59.2 & (23.6) & & & \\
\hline Galveston & 35 & 112.7 & 66.2 & (58.7) & 90.8 & (80.6) & $(21.9)$ & 56.3 & 62.4 \\
\hline Jacksonville & 73 & 168.0 & 102.2 & (60.8) & 149.9 & (89.2) & (28.4) & 50.6 & 33.1 \\
\hline Mobile & 12 & 192.2 & 137.2 & (71.4) & 190.7 & (99.2) & (27.8) & 161.3 & 145.6 \\
\hline New Orleans & 33 & $1,254.9$ & 172.6 & (13.8) & 219.2 & (17.5) & (3.7) & 183.2 & 94.3 \\
\hline Savannah & 10 & 63.4 & 62.6 & (98.6) & 62.9 & (99.1) & (0.5) & 54.7 & 54.7 \\
\hline Wilmington & 138 & 631.9 & 73.3 & (11.6) & 74.1 & (11.7) & $(0.1)$ & 8.0 & 14.0 \\
\hline Totals & 332 & $2,673.6$ & 625.2 & (23.4) & 846.8 & (31.7) & (8.3) & 515.1 & 404.9 \\
\hline
\end{tabular}

${ }^{1} \mathrm{~N}$ refers to the number of projects samples.

${ }^{2}$ This column is the percent of habitat alterations accepted by the NMFS subtracted from the percent permitted by the COE. ${ }^{3}$ Numbers in parentheses refer to percent of the acreage proposed

the NMFS is involved with and the lack of manpower to allow a greater amount of follow-up. For example, NMFS biologists attend many pre-application meetings at which projects are modified to reduce their impact on wetlands before the applicant requests a permit from the COE. Therefore, many of these projects result in minimal environmental impact. Many of the habitat losses tracked also may be small, yethave a large adverse impact that is not reflected by the area of proposed alterations that are reported. Examples include fill deposits which alter hydrologic patterns within estuaries, create barriers that block access to marine organisms, and alter sediment and freshwater inflow needed to nourish the marshes and maintain salinity gradients.

The area of proposed habitat alterations reported represents only the wetlands and other coastal areas which sup- port fishery resources under the purview of the NMFS. Lacustrine, palustrine, and riverine wetlands that do not support marine, estuarine, or anadromous fishery resources generally are not included in our data base. The FWS, the EPA, and state and local wetland conservation agencies also may have overlapping programs that involve an additional, but usually unquantified wetland acreage. Also, many nationwide and general permits now exist which give blanket authorization to thousands of projects each year that we are unable to monitor.

Discussions are currently underway among a number of Federal and state environmental and regulatory agencies on a "no net loss of wetland" concept proposed by U.S. President George Bush. Methods to achieve this goal are being discussed at various levels and 
efforts to define the concept are underway. The NMFS habitat program in the southeast has evolved to focus available resources where the best chances for minimizing habitat losses can be achieved. The approach we have taken, i.e., priority given to involvement with the civil works and regulatory programs of the COE, is based on NMFS data which demonstrates that 99 percent of the potential habitat alterations tracked falls under these programs. If the NMFS recommendations would be fully incorporated, the loss of wetlands supporting resources under NMFS purview can be reduced to levels approaching the goal of no net loss, at least for those habitat losses that can be regulated.

\section{Conclusions}

Data collected by the NMFS document the significance of the Federal regulatory and construction programs in managing human induced wetland alterations in the southeast. The NMFS is only partially effective in getting its conservation recommendations included in approved waterdevelopment projects. However, the amount of habitat potentially conserved and permitted demonstrates the importance of the NMFS involvement.

In view of the cumulatively large area of wetlands which could be altered through the COE regulatory and civil works programs, we believe there is ample justification for some COE districts to increase the rate at which they accept and incorporate the NMFS and other resource agency recommendations in the public in- terest review process. This would be a positive step toward minimizing habitat losses that can be directly controlled by man and would especially be necessary to reach a goal of no further wetland loss.

\section{Acknowledgments}

I am grateful to the following for providing the basic data for this paper: Larry Hardy, Ron Sechler, and Arlene Bossie in Beaufort, N.C.; Edwin Keppner, Mark Thompson, David Nixon, Shelly Du Puy, and Carol Parker in Panama City, Fla.; Rickey Ruebsamen, Peggy Jones, and Jan Koellen, in Baton Rouge, La.; and Don Moore, Rita Engblom, Sue Peck, and Ofilia VanderVort, in Galveston, Tex. Bob LaFollette and Cheryl Franzen provided computer support. Review and constructive comments were provided by Jim Cowan, John Hall, Larry Hardy, Gary Peterson, Rickey Ruebsamen, and Gordon Thayer.

\section{Literature Cited}

Alexander, C. E., M. A. Broutman, and D. W. Field. 1986. An inventory of coastal wetlands of the USA. U.S. Dep. Commer., NOAA, Wash., D.C., 14 p.

Cowardin, L. M., V. Carter, F. C. Golet, and E. T. LaRoe. 1979. Classification of wetlands and deepwater habitats of the United States. U.S. Fish Wildl. Serv. 103 p.

Craft, C. B., S. W. Broome, and E. D. Seneca. 1988. Nitrogen, phosphorus and organic carbon pools in natural and transplanted marsh soils. Estuaries 11(4):272-280.

Douglas, P. A., and R. H. Stroud (editors). 1971. A symposium on the biological significance of estuaries. Sport Fish. Inst., Wash., D.C., 111 p. Lindall, W. N., Jr., and G. W. Thayer. 1982. Quantification of National Marine Fisheries Service habitat conservation efforts in the Southeast Region of the United States. Mar. Fish. Rev.
44(12):18-22.

, A. Mager, Jr., G. W. Thayer, and D. R. Ekberg. 1979. Estuarine habitat mitigation planning in the southeast. In G. A. Swanson (tech. coord.), The mitigation symposium: A national workshop on mitigating losses of fish and wildlife habitats, p. 129-135. U.S. For. Serv., Rocky Mt. For. Range Exper. Sta., Gen. Tech. Rep. RM-65.

Mager, A., Jr. and E. J. Keppner. 1987. National Marine Fisheries Service habitat conservation efforts in the coastal southeastern United States for 1986. In N. V. Brodtmann, Jr. (editor), Fourth Water Quality and Wetlands Management Conference Proceedings. New Orleans, Louisiana. September 24-25, 1987, p. 49-70. La. Assoc. Environ. Prof.

and G. W. Thayer. 1986. National Marine Fisheries Service habitat conservation efforts in the Southeast Region of the United States from 1981 through 1985. Mar. Fish. Rev. 48(3):1-8.

and Ruebsamen. 1988. National Marine Fisheries Service habitat conservation efforts in the coastal southeastern United States for 1987. Mar. Fish. Rev. 50(3):43-50.

Peters, D. S., D. W. Ahrenholz, and T. R. Rice. 1979. Harvest and value of wetland associated fish and shellfish. In P. E. Greeson, J. R. Clark, and J. E. Clark (editors), Wetland functions and values: The state of our understanding, p. 606617. Am. Water Resour. Assoc., Minneapolis.

Smith, R. F., A. H. Swartz, and W. H. Massman (editors). 1966. A symposium on estuarine fisheries. Am. Fish. Soc. Spec. Publ. 3, 154 p.

Race, M. S. 1982. Coastal zone development; Mitigation, marsh creation, and decision-making. Environ. Manag. 6(4):317-328.

1985. Critique of present wetlands mitigation policies in the United States based on an analysis of past restoration projects in San Francisco Bay. Environ. Manag. 9(1):71-82

Thayer, G. W., and J. F. Ustach. 1981. Gulf of Mexico wetlands: Value, state of knowledge and research needs. In D. K. Atwood (convenor), Proceedings of a symposium on environmental research needs in the Gulf of Mexico(GOMEX), Vol. IIB, p. 1-30. Atl. Ocean. Meteorol. Lab., NOAA, Miami, Fla.

Turner, R. E. 1977. Intertidal vegetation and commercial yields of penaeid shrimp. Trans. Am. Fish. Soc. 106:411-416.

USCA. 1970. A. G. Zabel and D. H. Russellv. R.P. Tabb. United States Court of Appeals. 5 Cir. Docket No. 27555. 